\title{
Can Four Generations Create Harmony Within a Public-Sector Environment?
}

\author{
Glenda B. Arrington \\ Defense Media Activity, Fort Meade, Maryland \\ Rocky J. Dwyer \\ Walden University
}

\begin{abstract}
The purpose of this quantitative study was to examine the relationship between generational cohort and cohort perceptions of managerial effectiveness within the context of the federal public service. Data in this study were derived from the Federal Employee Viewpoint Survey, which included 421,748 full-time, part-time, and nonseasonal federal government employees geographically dispersed across the United States and overseas. The results of the study indicated that ratings of managerial effectiveness by all four generational cohorts for all three levels of managers studied were relatively high with correlation coefficients ranging from .96 to .99. However, the only cohort association that consistently had a statistically significant relationship with managerial effectiveness across all three levels was Generation Xers and Millennials. The $p$ value for this relationship was $p<.05$ for all three managerial levels studied. Based on the study's data, there was little difference in perceptions regarding managerial effectiveness among the four cohorts. Recommendations for future research include adding perspectives from Generation $\mathrm{Z}$ employees who are now entering the federal workforce, and studying how supervisors rate their own supervisors, given their unique managerial experience and perspective within the context of their generational cohort, would add to the body of knowledge on managerial effectiveness among generational cohorts.
\end{abstract}

Keywords: managerial effectiveness, generation cohorts, federal public sector, public-sector workforce, organizational effectiveness

\section{Introduction}

In today's work environment, managers now must lead the newest workforce entrants-Generation Z (Stuckey, 2016). Members of the Generation Z cohort are individuals born between 1995 and 2015; and by 2020 , Generation $Z$ will comprise $18 \%$ of the world's population. Stuckey further predicts $78 \%$ of leaders are ill equipped to manage Generation $\mathrm{Z}$ requirements against the conflicting needs of Traditionalists, Baby Boomers, Generation Xers, and Millennials. With so few managers prepared for the arrival of Generation Z, the disconnection of leaders' understanding of what will attract and retain Generation Zs in the workforce is no surprise (Dwyer \& Azevedo, 2016). Stuckey (2016) identified that $36 \%$ of leaders have received training on how to lead Generation Z employees, which shows promise because Generation $\mathrm{Z}$ will soon be in the position to make drastic changes in the workplace influenced by their cultures, ethics, and values. From the literature, we know this newest workforce generation is Internet savvy and lives in the virtual world (Kick, Contacos-Sawyer, \& Thomas, 2015). Furthermore, there is a realization that Generation $\mathrm{Z}$ requires fewer directions because they are the generation with ready access to digital tools enabling them to think they can do anything (Renfro, 2015). 
Historically, the federal public-sector workforce had been shared by generations with less diversity; however, currently, the changing workforce requires that managers understand the dynamics of each generation in today's federal public-sector workforce (U.S. Government Accountability Office [GAO], 2015). Members of these four generations bring their goals, values, and beliefs to the workplace, requiring managers to understand multiple generations effectively to manage the workforce (Maier, Tavanti, Bombard, Gentile, \& Bradford, 2015). Organizational climate has a significant influence on organizational effectiveness (Kataria, Garg, \& Rastogi, 2013). Management requires employees to perform at the peak level of their potential; however, it is a two-way process (Turner, Swart, Maylor, \& Antonacopoulou, 2016). Efforts are needed on the part of the managers in the organization to develop employees to succeed at work. The different views of an organization result from an evolving workforce that now includes these four generations (Lyons \& Kuron, 2014). With this information in mind, managers must understand the relationships between each generation's views and perceptions of effective management practices (Valcour, 2013). For this reason, recognizing and understanding the diverse views of workplace differences without showing preference among the four generations challenges managers (Dixon, Mercado, Knowles, 2013). Therefore, managers must understand the differences in each generation to lead an effective organization (Mencl \& Lester, 2014).

Interestingly, the employees' views of management practices improve as managers understand the impact of each generation's view of what constitutes effective management practices (Maier et al., 2015). Managers who understand the differences in employee's views of individual management practices are more likely better equipped to supervise effectively the multigenerational (Blackman, Buick, O'Flynn, O'Donnell \& West, 2017; Dwyer \& Azevedo, 2016). This awareness provides managers with tools to increase organizational effectiveness in the workplace (Van Velsor \& Wright, 2013). Fundamentally, managers should remain cognizant of the influences that affect their employees such as generation-based views that can influence the effectiveness of the organization (Carrison, 2014) because this presence of multigenerational cohorts in the workforce produces the single biggest challenge to leaders (Dwyer \& Azevedo, 2016). Dunlap (2014) agreed that multigenerational diversity of experiences and values based on different cohorts can cause challenges in the workplace. Each generation represents a varied set of morals and values influenced by the generational cohort in which they were born (Arunchand \& Ramanathan, 2013). Woodward, Vongswasdi, and More (2015) determined the generational cohort concept is well documented and was known to exist since the 1940s. Currently, each of the four generational cohorts brings a variety of knowledge, skills, social experiences, values, and motivations to the workplace (Mencl \& Lester, 2014). These skills and social experiences shape the value system of each generational cohort.

Because each generational cohort has its unique attributes, senior leaders and managers should possess management styles that adapt to the differences of each generational cohort (Mencl \& Lester, 2014). The authors suggested that generational differences do exist. Further, their research indicated that workplace characteristics across generational cohorts may be more similar than different. Having three or more generations in the workplace requires flexibility in managing the multigenerational workforce (Zhu, 2013). Managers face challenges of responding to employees' perceptions, which can affect organizational values. Zhu further suggested that a workforce with diverse skills can bring new techniques to the organization, thereby, strengthening the effectiveness and capability of the organization. Therefore, managers can tailor the leadership style to suit the employees and not the preference of the managers.

Recognizing generational disparities is crucial to achieving success to meet mission requirements for an effective organization (Mencl \& Lester, 2014). Similarly, understanding employees' views among the four generations provides managers of the federal public-sector workplace with opportunities to 
excel and manage difficult challenges (Arunchand \& Ramanathan, 2013). Federal public-sector managers can use employees' views to support more effective management practices (McDonald, 2014). Indeed, more precisely, a better understanding of employees' views among the four generations in the federal public-sector government is essential to the success of the federal publicsector workplace (McDonald, 2014). Creating an effective organization is an impetus for managers to understand their employees' views of management (U.S. GAO, 2015).

The root causes of unhealthy workplace relationships and ineffective organizations are systemic, which could conceivably engender a deficit in relationship building throughout the organization (Dunlap, 2014). Simplification and generalized differences among groups of employees can have significant implications on the effectiveness of an organization (Miller, 2014). Not surprisingly, no aspect of potential differences across generations has received as much attention as the differences between the work-related attitudes and values of the multigenerational workforce. These differences can influence perceptions and organizational effectiveness (Valcour, 2013). For this reason, managers must recognize and acknowledge differences among employees and explore viable means of creating workplace cohesion (VanMeter, Grisaffe, Chonko, \& Roberts, 2013).

Ignoring generational differences can lead to an ineffective organization (Miller, 2014). As understanding of generational differences increased, employee working relationships were better understood and, therefore, improved (Costanza \& Finkelstein, 2015). Researchers suggested there is still a need for more empirical data about the generations, the impact of the multigenerational workforce, and the generations' views of management practices in the organization (Arunchand \& Ramanathan, 2013).

\section{Research Boundary and Scope}

To contribute to the literature, we examined the relationship between generational cohorts and perceptions of managerial effectiveness within the context of the federal public-sector workplace at the managerial levels of senior leader, manager, and supervisor.

\section{Research Method and Limitations}

To conduct the research, a quantitative methodology was used to gather data from preexisting federal public-sector members, which enabled the researchers to examine the relationships between generational cohorts and managerial effectiveness. The population for this examination was 1,845,662 full-time, part-time, and permanent public-sector employees within the federal government during the first quarter of 2015 (U.S. Office of Personnel Management [OPM], 2015). The U.S. OPM sampled 848,237 federal employees in the federal government, which ensured a $95 \%$ chance that the true population value would be between plus or minus $1 \%$ of any estimated percentage of the total federal workforce (U.S. OPM, 2015). From those surveyed, 421,748 responses were received. These individuals constituted full-time and part-time employees; headquarters and field employees; supervisors and managers; veterans and nonveterans; individuals living with disabilities; individuals with varying educational backgrounds; members of lesbian, gay, bisexual, and transgender communities; and multiple racial and ethnic groups, all of whom worked in a vast array of occupations that make up the federal workforce. Members of the population represented 350 different occupations, 82 agencies, 37 departments and large agencies, and 45 small and independent agencies within the federal government. 
The survey instrument measured demographics, including age group, gender, race and ethnicity, disability status, previous military experience or veteran status, and workforce attributes (i.e., supervisor status and work location) at the government-wide level (U.S. OPM, 2015). The instrument measured the constructs using one of three 5-point Likert scales: 1 (strongly disagree, very dissatisfied, or very poor), 2 (disagree, dissatisfied, or poor), 3 (neither agree nor disagree, neither satisfied nor dissatisfied, or fair), 4 (agree, satisfied, or good), or 5 (strongly agree, very satisfied, or very good).

Limitations in this study included the potential for the socioeconomic background of each participant to affect his or her worldview of the different generations and work ethics. In addition, external validity was self-reporting and was different from an actual occurrence. Finally, because participants may not have trusted the confidentiality of the web-based survey tool, they may have answered those questions that they considered to be true statements or facts. The final limitation in this study was the absence of raw data for each individual respondent, which impacted the potential for statistical analysis.

\section{Conceptual Framework}

The term generation arose from descriptions that strove to make sense of the principles between people born at different chronological times (Scherger, Nazroo, \& May, 2016). The starting period of a birth range ending with the decline of the birth range is considered a generation (Dixon et al., 2013). The four generations (i.e., Traditionalist, Baby Boomer, Generation X, and Millennial) are categorized as a set of human beings who have taken possession of society based on the time in which they lived (Leveson \& Joiner, 2014). This article has a basis within generational theory that suggests cohorts of individuals born in the same period of time experience significant life events in their formative years that predisposes them to similar values, attitudes, and beliefs (Mannheim, 1952). Whereas a generational cohort experiences similar life events, each cohort's reality is different due to the various stages of human development and collective group history (Twenge, Gentile, \& Campbell, 2015). Traditionalists grew up in a supportive family environment with their beliefs shaped by parental views. Traditionally, mothers were in the home, and fathers were the breadwinners. At a young age, they did not know luxury, nor did they borrow for purchases; they would save money and pay cash.

Baby Boomers' beliefs were shaped by family and friends, they were also the generation who grew up and saw the deterioration of the traditional family as divorce became popular (Fry, 2015). Mothers working out of the home led to an increase in divorces. The Generation X cohort has a spirit of mentoring and entrepreneurship (Woodward et al., 2015) and refutes the notion of being lazy, disloyal, and unwilling to sacrifice for their families and freedoms (Wiedmer, 2015). The Millennial cohort's beliefs are also shaped by television and world events. Education is a huge expense, and, like for Generation Xers, work-life balance is important.

\section{Literature Review}

The major aspects of effective organizations include being irrepressible in times of diversity and being willing to assist managers in achieving a better understanding of their management practices within the organization (Strom, Sears, \& Kelly, 2014). Organizational leadership from a macroperspective measures the impact the organization has on society. Alternately, organizational leadership from the microperspective views employees' interaction within an organization's measured effectiveness (Maier et al., 2015). 
Workforce generational-specific attitudes and values of significant life events about work are brought to work (Ascencio \& Mujkic, 2016). In fact, the four generations bring their goals, values, and beliefs to the workplace, requiring managers to understand the relationship of each generation to manage the workforce effectively (Maier et al., 2015). These skills and social experiences shape the value system of each generational cohort (Ozturk, Hancer, \& Im, 2014). These successive entries, shaped by societal institutions, were associated with behaviors and expectations (Gurwitt, 2013). Then, it stood to reason that the generational cohorts within the multigenerational workforce would make up the population of managers and employees. This led to challenges for managers involving the age differences of the generational cohorts in the workforce because of significant perceived generational differences (Luscombe, Lewis, \& Biggs, 2013).

The federal public-sector government needs to create and nurture long-term relationships between managers and employees that are built on trust (Ascencio \& Mujkic, 2016). Trust develops in the organization when managers and employees act only with integrity. However, organizational leaders need to be successful in fostering organizational effectiveness to obtain a level of trust (Ascencio \& Mujkic, 2016). Employees who execute the business of the government and who trust their managers view the organization as genuine and adequate (Lissy \& Venkatesh, 2014). As indicated by Ascencio and Mujkic (2016), these employees view their managers whom they trust as effective; in contrast, employees who view their managers as ineffective lose trust. Employees' level of confidence impacts the fairness of management assessments; therefore, with trust, employees are inclined to accept decisions that are made. Managers' trust is paramount for employees to become well rounded and effective in the organization (Linz, Good, \& Busch, 2015). Likewise, Twenge et al. (2014) suggested that trust leads to effective relationships. However, trust should be reciprocal between managers and employees to foster an effective environment (Ascencio \& Mujkic, 2016). That said, federal publicsector government employees and managers of the multigenerational workforce in the federal publicsector government have differing levels of trust (Lissy \& Venkatesh, 2014). The discussion of generations in the federal public-sector workforce is a topic that challenges federal public-sector managers to understand the generational differences (Luscombe et al., 2013). Generational differences affect organizational effectiveness in the workplace with regard to communication, recruiting and retention, team building, change management, motivation, and productivity (Schullery, 2013).

The federal public-sector workforce includes approximately 1,845,662 workers in at least 350 occupations within 82 agencies (U.S. OPM, 2015). These federal public-sector workers include Traditionalists (1\%), Baby Boomers (49\%), Generation Xers (39\%), and Millennials (11\%). The unique mission of the federal public-sector workforce provides critical services and functions for the American people through the oversight of taxpayers' dollars and includes securing the nation's defense (U.S. OPM, 2015). At this juncture, it is beneficial to point out that, as a result of the plummeting economy, two generations of federal public-sector workers are not retiring as predicted (Luscombe et al., 2013). Delay of retirement attribute to cutbacks, layoffs, and massive losses of retirement savings (Ertas, 2015).

\section{Four Generations in the Workplace}

Traditionalists are individuals born between 1922 and 1945. Traditionalists make up 1\% of the 1.8 million federal public-sector workers in the government (Stark \& Farner, 2015). They are viewed in the workplace as the brick builders for the corporate culture and are the oldest members of the workforce (Luscombe et al., 2013). Many in the Traditionalist generation are loyal to the organization and anticipated working a lifetime in one organization (Dunlap, 2014); they also accept supervisory direction (Hillman, 2014). This generation possesses a solid work ethic with a strong 
commitment to hierarchical organizations. The Traditionalists do not understand workers who do not sacrifice to improve the organization. Similarly, they do not understand other generations who opt to take the easy road up the corporate ladder (Omana, 2016). Traditionalists disengage with senior managers and coworkers if there is no respect for their wealth of experience or historical knowledge (Luscombe et al., 2013). Traditionalists are likely to follow rules, policies, procedures, and guidelines as a way to conduct business (Hillman, 2014). They place more importance on education as a way to get ahead and less emphasis on work-life balance (Perrone-McGovern, Wright, Howell, \& Barnum, 2014).

Baby Boomers are individuals born between 1946 and 1964 (Stark \& Farner, 2015). They focus on the mission of the organization and prefer group meetings to discuss work-related issues rather than an individual one-on-one meeting arrangement. Baby Boomers believe in money, title, and recognition and are loyal team members (Luscombe et al., 2013). They are self-indulgent and judgmental, and they are a generation of sharing workers (Berkovich, 2014). Baby Boomers enjoy learning and taking on new responsibilities. This generational cohort is dominant in the workforce, in part, due to working beyond retirement eligibility years (Stanley, Vandenberghe, Vandenberg, \& Bentein, 2013). The Baby Boomers stay in the workforce for economic reasons due to college-age children remaining or returning to the home as well as adult children returning home to live after from being on their own in the workforce (Boveda \& Metz, 2016). Additionally, Baby Boomers delay retirement because of loneliness when home alone and the belief that they are needed in the workplace (Luscombe et al., 2013). These reasons are partly why Baby Boomers are working beyond retirement eligibility years (Stanley et al., 2013).

Generation Xers are individuals born between 1965 and 1979 (Stark \& Farner, 2015). Generation Xers are loyal to their supervisors and not only exceed expectations, but also deliver results. Generation Xers focus on achieving results while demanding work-life balance (Stark and Farner, 2015). This generational cohort is also referred to as the sandwich generation; they may have feelings of inferiority, insecurity, ambivalence, and economic instability because they are told that they will never do as well as their parents (Woodward et al., 2015). The Generation X cohort is money conscious. They view education as a means to an end; as mentioned, work-life balance is important. Whereas the communication style is informal and sometimes abrupt, they crave feedback to determine how they perform. Generation Xers are individuals who want to change rules (Luscombe et al., 2013). They are doubtful of hierarchal organizational structures. This means that, when in doubt, they are not afraid to ask questions of people higher up the chain of command (Wiedmer, 2015). This generational cohort has a spirit of mentoring and entrepreneurship (Woodward et al., 2015).

Millennials (also referred to as Generation Y) are individuals born between 1980 and 2000 (Huppke, 2013). Millennials aspire to make an immediate impact in the workforce (Ertas, 2015). They have workplace values, need meaningful work to accomplish goals, and require continuous feedback. They are accustomed to constant change and, therefore, take risks (Andrea, Gabriella, \& Timea, 2016). The U.S. Census Bureau personnel estimated that Millennials make up the largest generation in the history of the U.S. workforce (Fry, 2015; U.S. Census Bureau, 2015). Millennials include employees just out of high school, recent college graduates, and employees who have been working in the workforce for a short period of time. They desire opportunities and challenges for constant growth (Hillman, 2014). The positive impact made by the Millennials in the federal public-sector government forces managers to challenge members of the other generations (Bursch \& Kelly, 2014). Millennials believe that they can master a job requirement more quickly than previous generations (Woods, 2016). Unlike the Traditionalists who follow rules, the Baby Boomers who challenge rules, 
and the Generation Xers who change the rules, Millennials create rules for themselves (Luscombe et al., 2013).

\section{Federal Public-Sector Workplace Managerial Levels}

From Traditionalists to Millennials, managers represent the face of the organization (Nelson \& Svara, 2015). At least three designated levels of managers face the challenge of understanding employees' perceptions of their effectiveness as managers. Senior leaders, managers, and supervisors represent the three levels of management within the federal public-sector government (U.S. OPM, 2015). Senior leaders in the federal public-sector government are referred to as senior executive service, senior level, or scientific of professional members and are charged with leading the federal public-sector government workforce (U.S. OPM, 2015). Managers in the federal public-sector government are responsible for the high-level success of a department or division providing guidance, planning goals, and directing employees to achieve mission readiness, thereby, ensuring overall department success (U.S. OPM, 2015).

Managers must understand the general objectives of a department or division to articulate the mission to their subordinates. Supervisors in the federal public-sector government are the first-line level supervisors responsible for overseeing groups of employees for day-to-day operations (Nygard, Siukola, \& Virtanen, 2013). This level of supervision requires that the employees report directly to supervisors on all matters of work performance. Supervisors are typically responsible for administrative actions such as employees' performance appraisals and leave approval. Supervisors assign, realign, or modify workload and take corrective action to resolve employee challenges only after engaging with managers. The supervisors have the least amount of authority in the government hierarchy among the levels of leaders

\section{Organizational Leadership}

For more than 50 years, studies were conducted to identify how managers improved the performance of organizations (Woodward et al., 2015). Researchers continue to ask the question of why some managers are more effective than others (Woodward et al., 2015). Leadership from 50 years ago has morphed into a different meaning for leadership today (Kilber, Barclay \& Ohmer, 2014). The increasingly complex technical and technological challenges require new processes and perspectives found outside of the existing knowledge base of the organization. Future leadership skills will place an emphasis on soft skills such as building relationships and collaboration of individual and group competencies. Employees require less supervision as they become more productive and efficient while engaged and motivated to exceed expectations. Leaders work hard to build the culture of the organization to deliver results while managing the challenges of the organization (Suk Bong, Thi Bich Hanh, \& Byung Il, 2015).

Federal public-sector workers of Traditionalist and Baby Boomer generations are working alongside Generation Xers and Millennials who are managers but young enough to be their children. This mixing of generations has become ordinary for the federal public-sector workforce of today (Burch \& Strawderman, 2014). Multiple researchers have shown how managers of organizations could leverage management practices that foster an understanding of generational differences in the workforce (Costanza \& Finkelstein, 2015). A deeper knowledge and understanding of employees' views among the four generations of organizational demands, expectations, and beliefs in the federal public-sector workplace are essential for effective leadership and work accomplishment within the federal public-sector government (McDonald, 2014). As Ashforth, Schinoff, and Rogers (2014) pointed 
out, effective managers shape the organization through vision, interpersonal skills, technical abilities, and personal identification, thus delivering results.

Personal identification is necessary to measure the impact of the effectiveness of the organization. High levels of fit between organizational climate and people's preferences have positive impacts on the individual and the organization (Ashforth et al., 2014). Moreover, McCleskey (2014) suggested that a manager's style influences the effectiveness of the leader; effective leadership practices arise from a leader's focus on self, employees, and the organization (Suk Bong et al., 2014). Concurrently, the U.S. GAO (2015) suggested that ineffective leadership creates challenges that negatively affect federal public-sector agency's productivity, resulting in the inability to meet mission goals. To manage four generations appropriately in the workplace, managers must recognize the differences by understanding their perceptions of management practices in the workplace.

As postulated by Ellin (2014), once managers understand the employees' perceptions, they can build collaborative, interactive teams of generations and manage challenges that arise. At the same time, Dwyer and Azevedo's (2016) review of leadership styles suggested that generational differences are central in determining if a leadership style is preferred more by a particular generation and how this preference affects organizational success. The authors determined differences and similarities in leadership styles of the generations. Both Valcour (2013) and Douglas, Howell, Nelson, Pilkington, \& Salinas (2015) identified that, by understanding generational differences and perceptions, managers can significantly improve the interaction among employees of different generations. VanMeter et al. (2013) claimed that the generational cohorts share traditional work values. However, the generations differ on their views of the role of managers.

An essential element to the success of an organization is leadership and, in particular, effective leadership (Akins, Bright, Brunson, \& Wortham, 2013). The bottom line of management and leadership is the record of accomplishment for having a fruitful organization. From the perspective of Ashforth et al. (2014), managers and leaders are evaluated based on their contributions to organizational outcomes. From the viewpoint of Phipps, Prieto, and Ndinguri (2013), growth and development of effective managers are vital for an effective organization. Managers learn by experimentation about the opportunities and limitations of their roles and, therefore, are the first to acknowledge and accept the uniqueness of generational differences (Nelson \& Svara, 2015). As explained by Omana (2016), the most efficient way to manage generational differences in the workplace is to understand the challenges of conflict between generational relationships and to improve the perception of managerial effectiveness. Semeijn, Van Der Heijden, and Van Der Lee (2014) submitted that managerial effectiveness evaluations occur at every level based on individual perception. The skills required to be effective managers are to recognize and understand behavior, attitudes, and views of the workforce (Rao, Rao, Sarkar, Mishra, \& Anwer, 2013). These skills integrate employees' and managements' views, leading to an effective organization (Faiz, 2013). The federal public-sector government delegates managers at the three levels to shape the effectiveness of the organizations (Lissy \& Venkatesh, 2014). It is critical for federal public-sector managers to create an environment to foster understanding of the perceptions among the four generations (Burch \& Strawderman, 2014). Failure to understand generational differences may cause misunderstandings and mixed signals (Dokadia, Rai, \& Chawla, 2015). Once managers understand the differences, they will institute a thorough process to manage generation differences, moving toward an effective organization (Ellin, 2014).

Managers and leaders influence society based on the generational cohort (Ahmad \& Ibrahim, 2015). Tension in the workplace that occurs between supervisors and subordinates regarding generational differences is attributed to a lack of managers' understanding of generational differences (Shin, Koh, 
\& Shim, 2015). Individual preferences among the generations make managers uneasy when managing the differences. Managers who understand generational differences add to the success of the organization. That said, managers who are sensitive to generational differences can leverage employee productivity, creating a model of shared vision of positive relationships. Generationally savvy managers view generational differences as an asset. Generationally savvy managers who learn critical factors of each generation can better understand multigenerational differences. These managers place their preconceived ideas and stereotypes aside to be open-minded about each generation's value (Linz et al., 2015). The ability for managers to enhance a positive viewpoint for their employees is profoundly associated with sustaining an effective organization (Kataria et al., 2013).

\section{Challenges in Managing a Four-Generation Workforce}

Managers perceive that the multigenerational workforce create an unprecedented stress on work relations (Costanza \& Finkelstein, 2015). Managers face the issue of understanding how to lead a multigenerational workforce in an effective manner (Mencl \& Lester, 2014). Indeed, they experience challenges with the integration of four generations in the workplace and the additional challenge of how each person from each generation views managerial practices in the federal public-sector government (Luscombe et al., 2013). Managers who are sensitive to the views of employees among the four generations must reinforce a positive viewpoint or change a negative view (Lissy \& Venkatesh, 2014). In consequence, managers must be attentive to the differences and relations among each generation to ensure the impact the organization's performance and outcomes are positive. Managers must acknowledge critical differences in characteristics among each generation and their perceptions of management practices.

Managerial actions affect employees' views (Turner et al., 2016). These managerial practices are likely to have different performance expectations in the workplace. As such, the multigenerational workforce has its unique perspective on how it views work (Maier et al., 2015). These perceptions create challenges for managers who must understand and support the four generational views (Maier et al., 2015). The multigenerational differences in views and perspectives create a climate for conflict and create barriers with an employee versus manager mentality, resulting in high employee turnover and decreased productivity. Multigenerational conflicts create negative influence in the workplace. Such conflicts also cause conflicts among each generation as well as within each generation (Maier et al., 2015). A loss of valuable work and negative influences consequently create more misunderstanding among managers (Kilber et al., 2014). Managers' lack of understanding of the multigenerational views adds to the generational confusion affecting the organizations' effectiveness (Wronka-Pospiech, 2016). Finding effective ways to mitigate misconceptions among managers and the four generations is essential to meet the needs of the organization (Maier et al., 2015). Negative influences result in loss of valuable workforce members and, consequently, create more misunderstanding among managers and the four generations (Woods, 2016). To minimize conflicts and maximize organizational effectiveness, managers are required to understand how each generation views management practices (Blackman et al., 2017).

Worldviews brought to the workplace are based on generational upbringing (Maier et al., 2015). Further, managers should understand that each generation has its unique worldviews, priorities, motivations, expectations, and perceptions of the federal public-sector workforce (Ellin, 2014). Employees' views among the four generations' upbringing are influenced by a guardian or parental (Ertas, 2015). Traditionalists and Baby Boomers view rules as hierarchical; however, Generation Xers and Millennials do not (Ertas, 2015). Leaders at all levels can use this information to manage expectations of the generations. Managers narrowing the gap between generational cohorts increase 
management understanding, thereby improving organizational effectiveness (Colbert, Yee, \& George, 2016). Reducing these gaps is essential to understanding reasons for employees' views among the four generations (Dixon et al., 2013). As such, managers bridge the gap between different generational cohorts to improve organizational effectiveness of divergent employee views and values. This creates an effective environment for managers, employees, and the organization (Colbert et al., 2016).

\section{Federal Public-Sector Workforce}

Generational backgrounds influence generational perceptions of the workforce (Khera \& Malik, 2014). As pointed out Luscombe et al. (2013), through the lenses of the four generations, the federal public-sector workforce dramatically shifted in cultural changes of values and beliefs. Interestingly, the Success Factors study showed that $34 \%$ of executives were prepared to lead a diverse workforce (Abel-Lanier, 2016). Therefore, executives who were ill prepared were ineffective in driving the organization to success (Abel-Lanier, 2016).

Four generations are now working side by side in the same organization, and this side-by-side generational working relationship results in generational cohorts' diverse backgrounds (Ellin, 2014). As pointed out by Khera and Malik (2014), managers must effectively manage the growing and evolving workforce of the four generations. There is an increase of generations in the workforce who are more technologically savvy than other generations in the workforce, causing conflict for managers to manage (Valcour, 2013). As well, Ellin (2014) identified the presence of a multigenerational workforce and the differences in each generational cohort require managers to utilize their experiences and their organization mission to develop strategies to support organizational effectiveness. As suggested by Ellin, managers who understand how to succeed in separating generational differences are successful in leading an effective organization.

The generation in which each cohort belongs affects attitudes and behaviors in the workplace and shapes their expectations of managers (Ellin, 2014). As such, generational differences often lead to misunderstandings and, ultimately, affect perceptions resulting in workplace conflict (Harvey, Madison, Martinko, Crook, \& Crook, 2014). Federal public-sector managers need to recognize generational differences and conflicts to understand and reduce major confrontations and misunderstandings in the workplace better. According to Valcour (2013), managers who identify and understand the perceptions of each generation improve the relationship between each of the generations.

\section{Generational Cohort Studies}

Historically, young people were recruited, trained, and built careers with the same company as they ascended through the hierarchy (Farrell \& Hurt, 2014). However, this is no longer the career model. Moreover, there is no longer the one-size-fits-all approach. Farrell and Hurt suggested that longterm developmental opportunities are no longer a desire of the younger generations in the workforce today. Younger generational cohorts tend to change jobs at a greater rate than previous generations. Previous generations were also more willing to accept nonupward career moves (Farrell \& Hurt, 2014). Ahmad and Ibrahim (2015) noted that 21st-century challenges have expanded the need for leaders to adjust their approaches to diverse workforce coordination.

The focus of competition has changed from contending to get a vast number of customers to pooling the current workforce knowledge for sustainment of the organization over a period of time. Ahmad and Ibrahim (2015) found that a pressing issue in organizations is the demographic shift on 
leadership associated with generational cohorts. The workforce encompassed generational cohorts of differing life experiences, career stages, and work experiences (Ahmad \& Ibrahim, 2015). Moreover, generational cohorts navigate through four phases in a lifecycle. Lee and Coleman (2014) further explained that generational effects denote experiences, whereas period effects denote influences from people regardless of age.

\section{Organizational Effectiveness}

Great leaders not only want to be in a position to lead, but also they have a high need for having power to have followers engaged (Woodward et al., 2015). Woods (2016) defined organizational effectiveness as the measure of how successful an organization is in meetings or exceeding its vision and mission. Poksinska, Swartling, and Drotz (2013) noted organizational effectiveness is complex, controversial, and difficult to intellectualize. Blackman et al. (2017), however, suggested that although some organizations may have understood challenges associated with managing, communicating, and motivating the workforce, they were slow to manage the perceptions that varied among the multigenerational workforce. Critical to the effectiveness of any organization is an effective leader with fully engaged followers (Akins et al., 2013). As such, fully engaged followers enhance positive work performance (Akins et al., 2013; Bright et al., 2013). Leaders shape the effectiveness of the organization; however, there is less of a willingness to assume significant roles to get the job done effectively (Murphy \& Clark, 2016). Organizational acumen is the power to distinguish truth achieved through experiences learned through trial and error. Organizational concerns now rest with the manager's ability to select the right managerial technique that addresses the concerns while, simultaneously, achieving organizational effectiveness (Woods, 2016). According to Nelson and Svara (2015), the federal public-sector workforce's generational diversity adds depth, breadth, and scope to an organization, but, in contrast, generational diversity can lead to a less favorable outcome if obstacles impede the attainment of broader organizational goals and results.

Effective organizations contribute to a positive psychological climate. A psychological climate within the organization creates favorable conditions where individuals are more likely to invest greater energy, time, and effort (Wang and Ma, 2013). Kataria et al. (2013) contended that work engagement and positive psychological constructs are factors in which employees are emotionally and physically dedicated, enthusiastic, and energized toward the fulfillment of the organization's goal. Further, Kataria et al. determined that work engagement is an essential element in enriching the effectiveness of an organization.

\section{Findings and Analysis}

Federal public-sector employees and units were extracted from the personnel database managed by OPM as part of the Enterprise Human Resources Integration-Statistical Data Mart (2013). The data were analyzed to answer three research questions and test the corresponding hypotheses.

\section{Research Questions}

Three research questions guided the study:

Question 1: How do generational cohorts relate to cohort perception of managerial effectiveness at the senior leader level in the federal workforce?

Question 2: How do generational cohorts relate to cohort perception of managerial effectiveness at the manager level in the federal workforce? 
Question 3: How do generational cohorts relate to cohort perception of managerial effectiveness at the supervisory level in the federal workforce?

\section{Hypotheses}

Formulated hypotheses to align with each of the study's three research questions were as follows:

Hypothesis 10: There is no statistically significant relationship between generational cohorts and cohort perception of managerial effectiveness at the senior leader level in the federal workplace.

Hypothesis $1_{a}$ : There is a statistically significant relationship between generational cohorts and cohort perception of managerial effectiveness at the senior leader level in the federal workplace.

Hypothesis 20: There is no statistically significant relationship between generational cohorts and cohort perception of managerial effectiveness at the manager levels in the federal workplace.

Hypothesis 2a: There is a statistically significant relationship between generational cohorts and cohort perception of managerial effectiveness at the manager levels in the federal workplace.

Hypothesis 30: There is no statistically significant relationship between generational cohorts and cohort perception of managerial effectiveness at the supervisory level in the federal workplace.

Hypothesis 3a: There is a statistically significant relationship between generational cohorts and cohort perception of managerial effectiveness at the supervisory level in the federal workplace.

The average frequency and corresponding percentage of generational cohort respondents for which data were calculated included 17,716 Traditionalists (1.1\%), 735,865 Baby Boomers (45.6\%), 641,547 Generation Xers (39.6\%), and 222,141 Millennials (13.7\%).

Descriptively, the research showed great similarity in how all the cohorts rated managerial effectiveness. When considering the composite managerial effectiveness values, all the cohorts rated managerial effectiveness relatively high. More specifically, in a possible range of rating value from 33 to 100 , all the ratings for each cohort were above 70 . The composite value for managerial effectiveness was highest among the cohorts for managerial effectiveness by supervisors and lowest for senior leaders. Further, there was nearly a 10-point difference among the cohorts between these two levels. Another notable finding was the order of managerial effectiveness across the three management levels. The composite value of managerial effectiveness corresponded to the distance of managerial level from the employee. For example, the closer the manager was to the respondent, the higher the perceived managerial effectiveness. In other words, managerial effectiveness by the federal public-sector Employee Viewpoint Survey respondents was higher for supervisors (values ranged from 84 to 87), who were generally one management level away from the respondent (e.g., direct reports). Likewise, managerial effectiveness by the federal public-sector Employee Viewpoint Survey respondents was lower for senior leaders (values ranged from 72 to 79 ), who were generally two or more managerial levels away from the respondent. 
The finding for Research Question 1 was that, overall, there was no statistically significant relationship between generational cohorts and their perceptions of managerial effectiveness at the senior leader level in the federal workplace. Five of six combinations of generational cohorts for this level of managerial effectiveness were not statistically significant $(p>.05)$. Therefore, the alternative hypothesis was accepted. Although there was a strong relationship between the combinations of all cohorts in relation to managerial effectiveness, the association between only Generation Xers and Millennials as related to managerial effectiveness was statistically significant.

Research Question 2 showed that, overall, there was no statistically significant relationship between generational cohorts and their perceptions of managerial effectiveness at the manager level in the federal workplace. Five of six combinations of generational cohorts for this level of managerial effectiveness were not statistically significant $(p>.05)$. Therefore, the alternative hypothesis was accepted. Although there was a strong relationship between the combinations of all cohorts in relation to managerial effectiveness, the association between only Generation Xers and Millennials as related to managerial effectiveness was statistically significant.

The finding for Research Question 3 was that, collectively, there was no statistically significant relationship between generational cohorts and their perceptions of managerial effectiveness at the supervisor level in the federal workplace. Five of six combinations of generational cohorts for this level of managerial effectiveness were statistically significant $(p>.05)$. Therefore, the alternative hypothesis was accepted. Although there was a strong relationship between the combinations of all cohorts in relation to managerial effectiveness, the association between only Generation Xers and Millennials as related to managerial effectiveness was statistically significant.

This research investigated the problem that leaders faced managerial challenges in supervising a multigenerational workforce in the federal government, which could influence the effectiveness of the workforce. Therefore, a premise of the study was that a better understanding of the relationship between generational cohorts and cohort perceptions of managerial effectiveness within the context of the federal workplace could be helpful to federal leaders in working with multigenerations. Omana (2016) determined the most efficient way to manage generational differences in the workplace is to understand the challenges of conflict between generational relationships and to improve the perception of managerial effectiveness.

Information related to this problem and this premise for the study was supported in the literature of Semeijn et al. (2014), who suggested that managerial effectiveness evaluations occur at every level based on individual perception. Moreover, before leaders can effectively manage differences among the generational cohorts, leaders at the levels of senior, manager, and supervisor must first understand the differences in each generation as demonstrated by the implication that each generational cohort has an association of a level of significance. Further, this was supported by Schullery (2013), who stated that generational differences affect the organizational effectiveness in the workplace from communication, recruiting and retention, team building, change management, motivation, and productivity.

The findings for the study demonstrated that there was not much difference between how the four generational cohorts viewed managerial effectiveness. This was in contrasts with Mencl and Lester (2013), who stated that differences of generational cohorts in the workforce lead to challenges for managers due to significant perceived generational differences. Further, the findings for this study were not consistent with Maier et al.'s (2015) determination, which showed that multigenerational differences in views and perspectives could foster a climate for conflict and create barriers with employees and managers. Such differences can cause conflicts among each generation as well as 
within each generation, ultimately causing a loss of valuable work and creating more misunderstanding among managers (Kilber et al., 2014). Based on these examples, agreement and disagreement relative to the results of the current study were found in the literature. Generally, there was agreement in the literature relative to the identified problem for this study, but most researchers disagreed with the overall results of this study.

In this study, we determined the results showed descriptive similarity of ratings of managerial effectiveness by each generational cohort for all three levels of managerial effectiveness measured in the study. The four generational cohorts rated managerial effectiveness at all three levels relatively high. More specifically, the ratings for each cohort were above 70 based on the rating value range of 33 to 100. The composite value for managerial effectiveness was highest among the cohorts for managerial effectiveness of supervisors with a cohort rating range of 84 to 87 . The rating was lowest for senior leaders, ranging from 72 to 79 . The composite value for managerial effectiveness at the individual survey item level was the highest for Traditionalists (83) and the lowest for Generation Xers (78). The results of the research study's descriptive statistics showed Traditionalists rated managerial effectiveness higher than all the other cohorts for all three management levels. This supported the theory that traditionalists more so than Generation Xers were likely to follow rules, policies, procedures, and guidelines as a way to conduct business and were inclined to continue working without complaints in an organization until they retired or the organization downsized (Hillman, 2014; Luscombe et al., 2013). Leaders face any number of challenges as managers; however, the findings of this research indicated that managing multiple generational cohorts may not lead to distinct perceptions of managerial ineffectiveness based on cohort membership. Possible reasons for this and the findings for this study included cross-generational buy-in to organizational mission and goals. Another reason could be that federal workforce leaders were well trained and practiced effective leadership qualities that worked for multiple generations. The strong associations between cohorts at each level of managerial effectiveness in this study were in contrast to the findings in studies by Hillman (2014) and Luscombe et al. (2013).

Managerial challenges associated with supervising a multigenerational workforce influence the effectiveness of the workforce. The results of this study supported management's understanding of the relationship between the views of four generations of federal employees and how these generations perceived managerial effectiveness in the federal workplace. Most of the literature on managerial effectiveness among generational cohorts showed generations viewed managerial effectiveness differently, which was not the case for this study. The findings of this research did not support the majority of previous studies.

For each research question, the perceptions of generational cohorts of managerial effectiveness at the three levels (i.e., senior leader, manager, and supervisor) in the federal public-sector workforce were tested. A correlation analysis was performed to determine if there was any relationship between generational cohort and cohort perception of managerial effectiveness at each of the three levels in the federal public-sector workplace. An analysis of variance statistic was used to identify which relationships were significant at the $95 \%$ confidence level $(p<.05)$. The researcher reviewed generational cohorts and managerial effectiveness based on five selected questions of managerial effectiveness for each level of senior, manager, and supervisor. In some cases, the p value showed the relationship between two cohorts was very close to being statistically significant when $p<.05$. For example, the Traditionalists-Baby Boomers association as related to managerial effectiveness at the manager level was at the $p$ value of .06 . Although the data showed consistently strong relationships between all generations and managerial effectiveness at all three levels, only the cohort association of Generation Xers with Millennial was consistently significant for each research question. The results from the analyses indicated that there was a strong relationship among generational cohorts 
and cohort perceptions of managerial effectiveness. However, overall, the alternative hypotheses were rejected for all three research questions because most of the relationships were not statistically significant.

\section{Conclusion}

This article provided a material understanding regarding generational cohorts and the relationship between cohorts and managerial effectiveness in the federal public-sector workplace. In doing so, it contributed to existing literature on understanding the relationship the body of knowledge relative to this topic. All generational cohorts had a very similar high rating for managerial effectiveness in the workplace. Overall, this study was not consistent with the most recent literature that suggests managerial effectiveness is not perceived effective across generational cohorts and that varying workplace perspectives lead to frustration and misunderstanding (Arunchand \& Ramanathan, 2013; Berkovich, 2014; Luscombe et al., 2013). Such differences caused conflicts among generations, ultimately caused a loss of valuable work and misunderstanding among managers (Kilber et al., 2014).

Historically, the federal public-sector workforce was shared by generations with less diversity; however, the workforce has changed and now requires managers to understand the dynamics of each generation in today's federal public-sector workforce (U.S. GAO, 2015). This multigenerational workforce represents individuals with varying beliefs, skills, knowledge, attitudes, and motivation. Such diversity affects communication, effectiveness, performance, and level of respect. The one-sizefits-all management style is no longer relevant with the four generations currently representing the largest portion of the federal public-sector workforce. These results provide a better understand of relationships between generational cohorts and cohort perceptions of managerial effectiveness within the context of the federal public-sector workplace. Moreover, the results serve as a notice to current managers about how different generational cohorts viewed managerial effectiveness. These results could further provide an opportunity to improve not only the relationships with between managers and their employees, but also how leaders manage overall. Leaders who maximize their understanding of generational differences increase the success of any organization.

In conclusion, this study supported that managers were doing a fairly good job as perceived by all generational cohorts. Moreover, managers appeared to be well trained and use good leadership techniques; however, they should remain vigilant to the changing age demographics in the federal public-sector workforce.

\section{References}

Abel-Lanier, K. (2016). Motivating the workforce of 2020. Washington, DC: Society for Human Resource Management.

Ahmad, H., \& Ibrahim, B. (2015). Leadership and the characteristic of different generational cohort towards job satisfaction. Procedia-Social and Behavioral Sciences, 204, 14-18. doi:10.1016/j.sbspro.2015.08.104

Akins, R., Bright, B., Brunson, T., \& Wortham, W. (2013). Effective leadership for sustainable development. E Journal of Organizational Learning \& Leadership, 11, 29-36. Retrieved from http://www.leadingtoday.org/weleadinlearning/Spring2013/Spring_Summer_2013_Akins.pdf

Andrea, B., Gabriella, H., \& Timea, J. (2016). Y and Z generations at workplaces. Journal of Competitiveness, 8, 90-106. doi:10.7441/joc.2016.03.06 
Arunchand, C. H., \& Ramanathan, H. N. (2013). Organizational culture and employee morale: A public sector enterprise experience. Journal of Strategic Human Resource Management, 2, 18.

Ascencio, H., \& Mujkic, E. (2016). Leadership behaviors and trust in leaders: Evidence from the U.S. federal public sector government. Public Administration Quarterly, 40, 156-179. Retrieved from https://www.questia.com/library/journal/1G1-444699627/leadership-behaviors-andtrust-in-leaders-evidence

Ashforth, B. W., Schinoff, B. S., \& Rogers, K. M. (2014). I identify with her, I identify with him: Unpacking the dynamics of personal identification in organizations. Academy of Management Review, 41, 28-60. doi:10.5465/amr.2014.0033

Berkovich, I. (2014). Between person and person: Dialogical pedagogy in authentic leadership development. Academy of Management Learning \& Education, 13, 245. doi:10.5465/amle.2012.0367

Blackman, D., Buick, F., O'Flynn, J., O’Donnell, M., \& West, D. (2017). Managing expectations to create high performance government. Public Personnel Administration. Advance online publication. doi:10.1177/0734371X17701544

Boveda, I., \& Metz, A. J. (2016). Predicting end-of-career transitions for baby boomers nearing retirement age. The Career Development Quarterly, 64, 153-168. doi:10.1002/cdq.12048

Burch, F., \& Strawderman, L. (2014). Leveraging generational differences to reduce knowledge transfer and retention issues in public administration. Public Administration Research, 3, 61-75. doi:10.5539/par.v3n2p61

Bursch, D., \& Kelly, K. (2014). Managing the multigenerational workplace. Retrieved from http://www.kenan-flagler.unc.edu/ /media/Files/documents/executivedevelopment/managingthe-multigenerational-workplace-white-paper.pdf

Carrison, D. (2014). Seeking advantages in cross-generational management. Industrial Management, $56,6$.

Colbert, A., Yee, N., \& George, G. (2016). The digital workforce and the workplace of the future. Academy of Management Journal, 59, 731-739. doi:10.5465/amj.2016.4003

Costanza, D. P., \& Finkelstein, L. M. (2015). Generationally based differences in the workplace: Is there a there? Industrial and Organizational Psychology: Perspectives on Science and Practice, 8, 308-323. doi:10.1017/iop.2015.15

Dixon, G., Mercado, A., \& Knowles, B. (2013). Followers and generations in the workplace. Engineering Management Journal, 25, 1-12. doi:10.4271/2011-0080

Dokadia, A., Rai, S., \& Chawla, D. (2015). Multigenerational differences in work attributes and motivation: An empirical study. Indian Journal of Industrial Relations, 5, 81-96. Available from https://www.researchgate.net/publication/303940730_Multigenerational_differences_in_work _attributes_and_motivation_An_empirical_study

Douglas, M., Howell, T., Nelson, E., Pilkington, L., \& Salinas, I. (2015). Improve the function of multigenerational teams. Nursing Management, 46, 11-13.

doi:10.1097/01.NUMA.0000459098.71482.c4

Dunlap, D. (2014). The role of cross-national knowledge on organizational ambidexterity: A case of the global pharmaceutical industry. Management Learning, 45, 458-476.

doi:10.1177/1350507613480099 
Dwyer, R. J., \& Azevedo, A. (2016). Preparing leaders for the multi-generational workforce. Journal of Enterprising Communities: People and Places in the Global Economy, 10, 281-305. doi:10.1108/JEC-08-2013-0025

Ellin, A. (2014). How their world makes sense to them. Psychology Today, 47, 63.

Enterprise Human Resources Integration-Statistical Data Mart. (2013). About our data: Ensuring the federal public sector government has an effective civilian workforce. Available from http://www.fedscope.opm.gov/datadefn/aehri_sdm.asp

Ertas, N. (2015). Turnover intentions and work motivations of millennial employees in federal service. Public Personnel Management, 44, 401-423. doi:10.1177/0091026015588193

Faiz, N. (2013). Impact of manager's reward power and coercive power on employee's job satisfaction: A comparative study of public and private sector. International Journal of Management and Business Research, 3, 383-392.

Farrell, L., \& Hurt, A. (2014). Training the millennial generation: Implications for organizational climate. E Journal of Organizational Learning \& Leadership, 12, 47-60. Retrieved from http://www.leadingtoday.org/weleadinlearning/Spring2014/Table\%20of\%20Contents.pdf

Fry, R., (2015). Millennials surpass Gen Xers as the largest generation in U.S. labor force. Retrieved from http://www.pewresearch.org/facttank/ 2015/05/11/millennials-surpass-gen-xers-as-thelargest-generation-in-u-slabor-force

Gurwitt, R. (2013). How Generation X is shaping government. Governing, 23, 28-35. Available from http://www.governing.com/topics/mgmt/gov-howgeneration-X-shaping-government.html

Harvey, P., Madison, K., Martinko, M., Crook, T. R., \& Crook, T. A. (2014). Attribution theory in the organizational sciences: The road traveled and the path ahead. The Academy of Management Perspectives, 28, 128-146. doi:10.5465/amp.2012.0175

Hillman, D. R. (2014). Understanding multigenerational work-value conflict resolution. Journal of Workplace Behavioral Health, 29, 240-257. doi:10.1080/15555240.2014.933961

Huppke, R. (2013, August 5). The cost of millennial job hopping. Chicago Tribune Business. Retrieved from http://www.chicagotribune.com/business/careers/ct-biz-0805-work-advicehuppke-20130805-column.html

Kataria, A., Garg, P., \& Rastogi, R. (2013). Psychological climate and organizational effectiveness: Role of work environment. The IUP Journal of Organizational Behavior, 12, 33-46. Retrieved from https://www.questia.com/library/journal/1P3-3077892671/psychologicalclimate-and-organizational-effectiveness

Khera, K., \& Malik, S., (2014). Life priorities and work preferences of Generation Y: An exploratory analysis in Indian context. Jindal Journal of Business Research. 3, 63-76. doi:10.1177/2278682116643607

Kick, A. L., Contacos-Sawyer, J., \& Thomas, B. (2015). How Generation Z's reliance on digital communication can affect future workplace relationships. Competition Forum, 13, 214-222. Retrieved from https://www.questia.com/library/p150669/competition-forum/i3927498/vol-13no-2-2015

Kilber, J., Barclay, A., \& Ohmer, D. (2014). Seven tips for managing Generation Y. Journal of Management Policy and Practice, 15, 80-91.

Lee, J. K., \& Coleman, R. (2014). Testing generational, life cycle, and period effects of age on agenda setting. Mass Communication and Society, 17, 3-25. doi:10.1080/15205436.2013.788721 
Leveson, L., \& Joiner, T. A. (2014). Exploring corporate social responsibility values of millennial jobseeking students. Education and Training, 56, 21-34. doi:10.1108/ET-11-2012-0121

Linz, S., Good, L. K., \& Busch, M. (2015). Promoting worker loyalty: An empirical analysis. International Journal of Manpower, 36, 169-191. doi:10.1108/IJM-06-2013-0129

Lissy, T. A., \& Venkatesh, J. (2014). Factors that influence the organizational commitment: A case of paramedical staff at private hospitals. International Journal of Multidisciplinary Approach \& Studies, 1, 195-206.

Luscombe, J., Lewis, I., \& Biggs, H. C. (2013). Essential elements for recruitment and retention: generation Y. Education \& Training, 55, 272-290. doi:10.1108/00400911311309323

Lyons, S. T., \& Kuron, L. (2014). Generational differences in the workplace: A review of the evidence and directions for future research. Journal of Organizational Behavior, 35, 139-157. doi:10.1002/job.1913

Maier, T., Tavanti, M., Bombard, P., Gentile, M., \& Bradford, B. (2015). Millennial generation perceptions of value-centered leadership principles. Journal of Human Resources in Hospitality \& Tourism, 14, 382-397. doi:10.1080/15332845.2015.1008386

Mannheim, K. (1952). The problem of generations. In P. Kecskemeti (Ed.), Essays on the sociology of knowledge (pp. 276-320). New York, NY: Routledge \& Kegan Paul.

McCleskey, J. A. (2014). Situational, transformational, and transactional leadership and leadership development. Journal of Business Studies Quarterly, 5, 117-130. Retrieved from http://jbsq.org/wp-content/uploads/2014/06/June_2014_9.pdf

McDonald, P. (2014). Developing millennials into your firm's next generation of leaders. Financial Executive, 30, 8-9. Retrieved from http://daily.financialexecutives.org/developing-millennialsfirms-next-generation-leaders/

Mencl, J., \& Lester, S. (2014). More alike than different: What generations value and how the values affect employee workplace. Journal of Leadership and Organizational Studies, 21, 257-272. doi:10.1177/1548051814529825

Murphy, C., \& Clark, J. R. (2016). Picture this: How the language of leaders drives performance. Organizational Dynamics, 45, 139-146. doi:10.1016/j.orgdyn.20 16.02.008

Miller, S. P. (2014). Next-generation leadership development in family businesses: The critical roles of shared vision and family climate. Frontiers in Psychology, 5, 1335.

doi:10.3389/fpsyg.2014.01335

Nelson, K. L., \& Svara, J. H. (2015). The roles of local government managers in theory and practice: A centennial perspective. Public Administrative Review, 75, 49-61. doi:10.1111/puar.12296

Nygard, C., Siukola, A., \& Virtanen, P. (2013). Attitudes and arrangements at workplace and sickness absence among blue- and white-collar workers. International Journal of Workplace Health Management, 6, 143-156. doi:10.1108/IJWHM-05-2012-0011

Omana, N. (2016). Generational delivery strategies: What, when, where, and for whom. Workforce Solutions Review, 7, 7-10.

Ozturk, A. B., Hancer, M., \& Im, J. Y. (2014). Job characteristics, job satisfaction, and organizational commitment for hotel workers in Turkey. Journal of Hospitality Marketing \& Management, 23, 294-313. doi:10.1080/19368623.2013.796866 
Perrone-McGovern, K. M., Wright, S. L., Howell, D. S., \& Barnum, E. L. (2014). Contextual influences on work and family roles: Gender, culture, and socioeconomic factors. The Career Development Quarterly, 62, 21-28. doi:10.1002/j.2161-0045.2014.00067

Phipps, S. T., Prieto, L. C., \& Ndinguri, E. N. (2013). Understanding the impact of employee involvement on organizational productivity: The moderating role of organizational commitment. Journal of Organizational Culture, 17, 107-120.

Poksinska, B., Swartling, D., \& Drotz, E. (2013). The daily work of lean leaders: Lessons from manufacturing and healthcare. Total Quality Management and Business Excellence, 24, 886898. doi:10.1080/14783363.2013.791098

Quick, J., \& Hall, S. (2015). Part three: The quantitative approach. Journal of Perioperative Practice, 25, $192-196$.

Rao, R. V. S., Rao, K. H., Sarkar, A., Mishra, D., \& Anwer, M. M. (2013). Leadership effectiveness of scientists in Indian Council of Agricultural Research. IUP Journal of Organizational Behavior, 12, 24-40. Retrieved from http://www.iupindia.in/1301/Organizational\%20Behavior/Leadership_Effectiveness_of_ Scientists.html

Renfro, A. (2015). Meet Generation Z. Retrieved from http://gettingsmart.com/2015/12/meetgeneration-z/

Scherger, S., Nazroo, J., \& May, V. (2016). Work and family trajectories: Changes across cohorts born in the first half of the 20th century. Population Ageing, 9, 131-155 doi:10.1007/s12062-0159128-9

Schullery, N. M. (2013). Workplace engagement and generational differences in values. Business Communication Quarterly, 76, 252-265. doi:10.1177/1080569913476543

Semeijn, J. H., Van Der Heijden, B. M., \& Van Der Lee, A. (2014). Multisource ratings of managerial competencies and their predictive value for managerial and organizational effectiveness. Human Resource Management, 53, 773-794. doi:10.1002/hrm.21592

Shin, Y. B., Koh, S. H., \& Shim, C. S. (2015). Information processing model to measure important determinants on job satisfaction. Journal of Business and Retail Management Research, 9, 100-109.

Stanley, L., Vandenberghe, C., Vandenberg, R., \& Bentein, K. (2013). Commitment profiles and employee turnover. Journal of Vocational Behavior, 82, 176-187.

doi:10.1016/j.jvb.2013.01.011

Stark, E., \& Farner, S. (2015). Intergenerational warfare in the U.S. workplace or nothing more than growing pains? SAM Advanced Management Journal, 80, 4-11.

Strom, D. L., Sears, K. L., \& Kelly, K. M. (2014). Work engagement: The roles of organizational justice and leadership style in predicting engagement among the employees. Journal of Leadership and Organizational Studies, 21, 71-82. doi:10.1177/1548051813485437

Stuckey, C. (2016, October). Preparing leaders for Gen Z. Training Journal, 10, 33-35. Retrieved from https://www.trainingjournal.com/articles/opinion/preparing-leaders-gen-z

Suk Bong, C., Thi Bich Hanh, T., \& Byung Il, P. (2015). Inclusive leadership and work engagement: Mediating roles of affective organizational commitment and creativity. Social Behavior \& Personality: An International Journal, 43, 931-943. doi:10.2224/sbp.2015.43.6.931 
Turner, N., Swart, J., Maylor, H., \& Antonacopoulou, E. (2016). Making it happen: How managerial actions enable project-based ambidexterity. Management Learning, 47, 199-222. doi:10.1177/1350507615610028

Twenge, J. M., Gentile, B., \& Campbell, W. K. (2015). Birth cohort differences in personality. In M. Mikulincer, P. R. Shaver, M. L. Cooper, \& R. J. Larsen (Eds.), APA handbook of personality and social psychology (Vol. 4): Personality processes and individual differences (pp. 535-551). Washington, DC: American Psychological Association. doi:10.1037/14343-024

U.S. Census Bureau. (2015, June 25). Millennials outnumber Baby Boomers and are far more diverse, Census Bureau reports. Retrieved from https://www.census.gov/newsroom/pressreleases/2015/cb15-113.html

U.S. Government Accountability Office (GAO). (2015). Trends in federal public sector civilian employment and compensation. Retrieved from http://www.gao.gov/products/GAO-14-215

U.S. Office of Personnel Management (OPM). (2015). U.S. Office of Personnel Management announces the 2015 Federal public sector Employee Viewpoint Survey [News Release]. Retrieved from http://www.opm.gov/news/release/2015/05/opm-announces-the-2015-federal public sector employee viewpoint-survey

Valcour, M. (2013). Hitting the intergenerational sweet spot. Harvard Business Review. Retrieved from https://hbr.org/2013/05/hitting-the-intergenerational

VanMeter, R. A., Grisaffe, D. B., Chonko, L. B., \& Roberts, J. A. (2013). Generation Y's ethical ideology and its potential workplace implications. Journal of Business Ethics, 117, 93-109. doi:10.1007/s10551-012-1505-1

Van Velsor, E., \& Wright, J. (2013). What do next-generation leaders look like? Chief Learning Officer, 44-46. Retrieved from http://www.clomedia.com/2013/03/27/what-do-next-generationleaders-look-like/

Wang, G., \& Ma, X. (2013). The effect of psychological climate for innovation on salespeople's creativity and turnover intention. Journal of Personal Selling and Sales Management, 33, 373-387. doi:10.2753/PSS0885-3134330402

Wiedmer, T. (2015). Generations do differ: Best practices in leading traditionalists, baby boomers, and Generations X, Y, and Z. Delta Kappa Gamma Bulletin, 82, 51-58.

Woods, K. (2016). Organizational ambidexterity and the multigenerational workforce. Journal of Organizational Culture, Communications, and Conflict, 20, 95-111. Retrieved from http://www.alliedacademies.org/articles/jocccvol-20issue1.pdf

Woodward, I. C., Vongswasdi, P., \& More, E. A. (2015). Generational diversity at work: A systematic review of the research. INSEAD Working Papers Collection, 48, 1-71. Retrieved from https://sites.insead.edu/facultyresearch/research/doc.cfm?did=56531

Wronka-Pospiech, M. (2016). The identification of skills and competencies for effective management in social enterprises: A managerial perspective. Management, 20, 40-57. doi:10.1515/manment-2015-0023

Zhu, Y. (2013). A review of job satisfaction. Asian Social Science, 9, 293-298. doi:10.5539/ass.v9n1p293 
The International Journal of Applied Management and Technology (IJAMT), sponsored by Walden University's School of Management, is a peer-reviewed, online journal that addresses contemporary national and international issues related to management and technology. The objectives of the IJAMT are to: (a) encourage collaborative and multi-disciplinary examinations of important issues in business and technology management, and (B) engage scholars and scholar-practitioners in a dynamic and important dialogue.

Walden University Publishing: http://www.publishing.waldenu.edu 